\title{
Resistance to acetylsalicylic acid in patients with type 2 diabetes mellitus is associated with lipid disorders and history of current smoking
}

\author{
B. Labuz-Roszak $\cdot$ K. Pierzchała $\cdot$ K. Tyrpień
}

Received: 4 January 2013/Accepted: 17 November 2013/Published online: 9 January 2014

(C) The Author(s) 2013. This article is published with open access at Springerlink.com

\begin{abstract}
Background Diabetes mellitus (DM) is an important risk factor for stroke. Acetylsalicylic acid (ASA) is the most frequently used medication for prevention of cardio-cerebral vascular diseases. However, some patients experience ischaemic vascular events despite the use of ASA. This phenomenon is known as "aspirin resistance" (AR). The aim of this study was to assess the prevalence of AR in diabetic patients and search for factors associated with it. Materials and methods The examined group consisted of 96 subjects with diagnosed type 2 DM. Platelet function test was performed by the method of whole blood impedance aggregometry.

Results Among examined subjects, 51 patients (53.1\%) were sensitive to ASA action (ASA responders) and 45 patients $(46.9 \%)$ were resistant to ASA action (ASA nonresponders). No association was found between platelet aggregation and gender, age, dose of ASA, known duration of diabetes, BMI, heart rate, mean systolic and diastolic blood pressure, and risk factors except for current smoking $(p=0.030)$. ASA non-responders were treated shorter with ASA than ASA responders $(p=0.010)$. The mean total cholesterol $(p=0.020), \quad$ LDL concentration $(p=0.005)$, HCT $(p=0.010)$, WBC $(p=0.030)$, and
\end{abstract}

B. Łabuz-Roszak $(\square) \cdot$ K. Pierzchała

Department of Neurology in Zabrze, Medical University of

Silesia, 3-go Maja 13/15, 41-800 Zabrze, Poland

e-mail: beatamaria.pl@hoga.pl

K. Tyrpień

Department of Chemistry, Medical University of Silesia,

Zabrze, Poland
PLT $(p=0.050)$ were significantly higher in ASA nonresponders. No association was found between AR and results of other laboratory tests and medications. Multiple logistic regression analysis revealed factors associated with AR: current smoking and LDL concentration higher than $3.5 \mathrm{mmol} / \mathrm{l}$.

Conclusions Results of our study did not confirm the association between poor glycaemic control in the diabetic patients and AR. Resistance to ASA in diabetic patients is associated with lipid disorders and history of current smoking.

Keywords Diabetes mellitus - Acetylsalicylic acid · Stroke $\cdot$ Aspirin resistance

$\begin{array}{ll}\text { Abbreviations } \\ \text { ACE } & \text { Angiotensin converting enzyme } \\ \text { AR } & \text { Resistance to acetylsalicylic acid } \\ \text { ASA } & \text { Acetylsalicylic acid } \\ \text { AUC } & \text { Area under curve } \\ \text { BP } & \text { Blood pressure } \\ \text { CBC } & \text { Complete blood count } \\ \text { CCB } & \text { Calcium channel blockers } \\ \text { CRP } & \text { C-reactive protein } \\ \text { DBP } & \text { Diastolic blood pressure } \\ \text { HCT } & \text { Haematocrit } \\ \text { HGB } & \text { Haemoglobin } \\ \text { NSAID } & \text { Non-steroidal anti-inflammatory drugs } \\ \text { PLT } & \text { Platelets } \\ \text { PPI } & \text { Proton pump inhibitors } \\ \text { RBC } & \text { Red blood cells } \\ \text { SCORE } & \text { Systematic coronary risk evaluation } \\ \text { SBP } & \text { Systolic blood pressure } \\ \text { SSRI } & \text { Selective serotonin reuptake inhibitors } \\ \text { WBC } & \text { White blood cells }\end{array}$

Abbreviations

Resistance to acetylsalicylic acid

ASA Acetylsalicylic acid

AUC Area under curve

BP Blood pressure

CBC Complete blood coun

Calcium channel blockers

C-reactive protein

DBP Diastolic blood pressure

Haematocrit

HGB Haemoglobin

NSAID Non-steroidal anti-inflammatory drugs

PLT Platelets

PPI Proton pump inhibitors

RBC Red blood cells

SCORE Systematic coronary risk evaluation

SBP Systolic blood pressure

WBC White blood cells 


\section{Introduction}

Diabetes mellitus (DM) is an important and common risk factor for stroke. People with DM suffer from cerebrovascular events 1.5-3 times more likely than people without disorders of carbohydrate metabolism. Acetylsalicylic acid (ASA) is the most frequently used medication for prevention of ischaemic events in diabetic patients. Recommendations for the cardiovascular prevention and usage of ASA in diabetic patients are nowadays similar to the general principles as for people without diabetes. Recent randomized clinical trials and meta-analyses did not confirm the effectiveness of ASA in primary prevention in diabetic patients without other risk factors [1-4]. Following the current European guidelines [5], ASA is recommended in all patients with an overt vascular disease (previous stroke, previous noncardioembolic cerebral transient ischaemic attack, coronary heart disease, previous myocardial infarction, peripheral artery disease). In asymptomatic people, also in diabetic patients, ASA could be considered when the risk of death from a cardiovascular disease is high (5\% or greater in the next 10 years). On the basis of the risk factors (gender, age, systolic blood pressure, total cholesterol and history of smoking), one can determine the risk of death from cardiovascular causes in patients aged 40 and older using tables of Systematic Coronary Risk Evaluation (SCORE) [5, 6].

In patients who regularly take ASA a $25 \%$ reduction of the incidence of myocardial infarction and ischaemic stroke was reported [7]. However, some patients do not experience the positive antiplatelet effect and have cardiovascular events despite the use of ASA. This phenomenon is known as "clinical aspirin resistance" (AR). This term is also used when laboratory test results indicate the lack of antiaggregative ASA action (known as "biochemical aspirin resistance").The prevalence of AR described in the literature is up to $60 \%$ among subjects taking ASA for primary or secondary prevention of cardiovascular episodes [8-15]. Some authors noticed that AR occurred more frequently in diabetic patients [16, 17]. The mechanism of AR has not been fully understood as yet. Genetic factors are considered together with patient non-compliance, low dose of the drug, interactions with other medications and substances [18]. In diabetic patients the role of glycaemic control was also studied but the data concerning association between poor control and AR are conflicting [16, 17, 19-21].

The aim of this study was to assess the prevalence of AR in diabetic patients and search for factors associated with this phenomenon.

\section{Materials and methods}

Subjects for the study were recruited in 2011-2012 years from patients treated in the Voivodship Outpatient Clinic for Diabetic Patients in Zabrze, Poland. The recruitment for the study was performed once a month. All the patients attending the outpatient clinic on the recruitment day were checked according to the inclusion and exclusion criteria. Only those who agreed to take part in the study and gave written consent were selected.

The inclusion criteria for the examined group were the following: diagnosed diabetes mellitus type 2, known cardiovascular disease (coronary heart disease, previous myocardial infarct, previous stroke or transient ischaemic attack, peripheral artery disease) or SCORE $>5 \%$, regular daily ASA intake at the dose of 75-150 mg/day, not using other antiplatelet and/or anticoagulant agents, age between 18 and 80 years, and the patient's informed written consent for the study.

Diabetes mellitus was diagnosed according to the current criteria of Polish Diabetological Society (clinical symptoms of hyperglycaemia and casual glycemia $\geq 200$ $\mathrm{mg} / \mathrm{dl}$ or twice measured fasting glycemia $\geq 126 \mathrm{mg} / \mathrm{dl}$ or glycemia in $120 \mathrm{~min}$ of OGTT $\geq 200 \mathrm{mg} / \mathrm{dl}$ ).

The 10-year risk of fatal cardiovascular disease (SCORE) was assessed using the following data: sex (male/ female), age (years), systolic blood pressure $(\mathrm{mmHg})$, total cholesterol (mmol/l) and history of current smoking [5, 6].

The exclusion criteria for the examined group were the following: the intake of other oral antiplatelet or anticoagulant agents, the use of other non-steroidal anti-inflammatory drugs (NSAIDs), irregular ASA intake, the use of heparin or low molecular weight heparin, platelet count $<100 \times 10^{3} / \mu 1$ or $>450 \times 10^{3} / \mu 1$, history of haemorrhage.

Patients with history of atrial fibrillation participating in this study had contradictions for usage of oral anticoagulant agents or did not agree for such treatment.

The regularity of ASA intake (one tablet per day) was determined based on the carefully obtained medical history. Besides, the intake of ASA was personally controlled by one of the authors on the day $(24 \mathrm{~h})$ before the study.

The study was approved by the Bioethics Committee of the Medical University of Silesia.

All patients were interviewed and underwent physical examination. Arterial hypertension was recognized in people treated with antihypertensive drugs and in those who presented abnormal BP in two measurements ( $\mathrm{SBP} \geq 140$ $\mathrm{mmHg}$ and/or DBP $\geq 90 \mathrm{mmHg}$ ). Dyslipidaemia was recognized in people treated with statins or fibrates and in those who revealed abnormal results of lipids (total cholesterol $\geq 4.5 \mathrm{mmol} / \mathrm{l}$ and/or $\mathrm{LDL} \geq 2.6 \mathrm{mmol} / \mathrm{l}$ and/or TG $\geq$ $1.7 \mathrm{mmol} / \mathrm{l})$. Coronary heart disease, previous myocardial 
Fig. 1 An example of platelet function analysis (ASPI test) with usage of multiple platelet function analyzer. Resistance to ASA was recognized in examined patient
Fig. 2 An example of platelet function analysis (ASPI test) with usage of multiple platelet function analyzer. Proper response to ASA was recognized in examined patient
Multiplate6 - V2.03.11

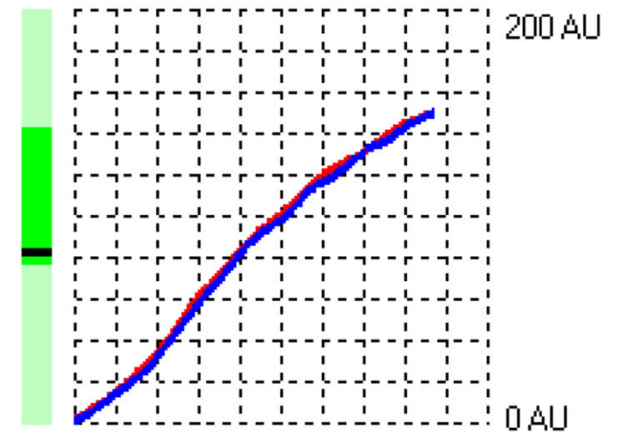

ASPItest (Hirudin blood]. V'1

28. 06. 2012, 11:18:17

AUC: 747 AUmin. [691 - 1294]

RUD: $150.0 \mathrm{AU}$

RUO: $15.8 \mathrm{AU} / \mathrm{min}$.
Multiplate6 - V2.03.11

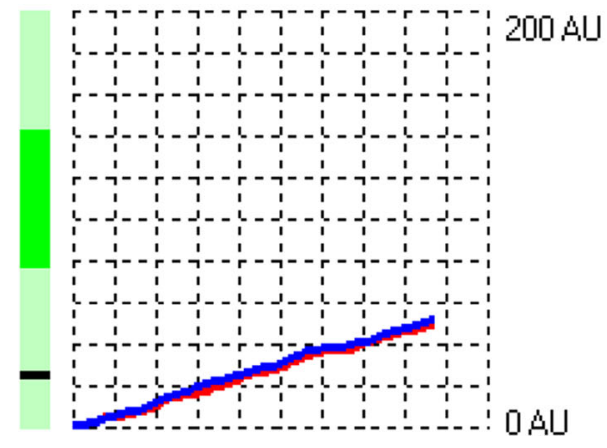

ASPItest [Hirudin blood]. V1

28. 06. 2012, 10:41:10

AUC : 229 ALmin. [691 - 1294]

RU0: $49.9 \mathrm{AU}$

P」D: $5.5 \mathrm{AU} / \mathrm{min}$. infarct and atrial fibrillation were recognized only when they were documented.

A 10-ml fasting blood sample was obtained to determine platelet function and additional laboratory tests (CBC, glucose, total cholesterol, LDL, HDL, triglycerides, $\mathrm{HbA}_{1} \mathrm{C}, \mathrm{CRP}$, creatinine). $\mathrm{CBC}$ was assessed by haematological analyzer Sysmex K-4500 ${ }^{\circledR}$ (Sysmex Polska), and glucose, total cholesterol, HDL, triglycerides, $\mathrm{HbA}_{1} \mathrm{C}$, CRP, creatinine-by biochemical analyzer Cobas Integra $800^{\circledR}$ (Roche). Concentration of serum LDL cholesterol was counted according to Friedwald schedule. The following methods were used: enzymatic colorimetric method (total cholesterol, triglycerides, HDL), Jaffe's method (creatinine), immune turbidmetric method $\left(\mathrm{CRP}, \mathrm{HbA}_{1} \mathrm{C}\right)$, reference enzymatic method (glucose).

Platelet function test was performed by the method of whole blood impedance aggregometry using multiple platelet function analyzer Multiplate ${ }^{\circledR}$ (Dynabyte Medical, Munich, Germany) [22, 23]. Aggregation was triggered by use of arachidonic acid (ASPItest). The results were expressed as the area under curve (AUC) (Figs. 1, 2).

Based on the manufacturer's data, it was accepted that in patients who take ASA the value of AUC $<300$ indicates aspirin sensitivity (ASA responders), and the value of AUC $\geq 300$ indicates aspirin resistance (ASA nonresponders) [22-24].

The obtained results underwent statistical analysis using STATISTICA 9.0, Stat Soft Poland. The result was considered statistically significant if obtained significance level was $p \leq 0.05$. In data description the standard statistical parameters were provided, i.e. the number $N$, arithmetic mean $X$, the standard deviation (SD) and percentages (\%). Normal distribution of data was assessed by Shapiro-Wilk normality test. Statistical significance of between-group differences was verified by $U$ Mann-Whitney test. Chi-squared test was utilized for comparison of qualified variables. Multiple logistic regression analysis was performed for searching factors associated with AR. Odds ratio (OR) and confidential interval (CI) were calculated for the following factors: age $>60$ years, male sex, dose of ASA $\leq 100 \mathrm{mg}$ per day, duration of ASA therapy $>1$ year, known duration of diabetes $>5$ years, $\mathrm{BMI}>25 \mathrm{~kg} / \mathrm{m}^{2}$, systolic blood pressure $\geq 140 \mathrm{mmHg}$, diastolic blood pressure $\geq 90 \mathrm{mmHg}$, heart rate $\geq 80 \mathrm{bpm}$, presence of each cardiovascular risk factor, each medication, $\mathrm{RBC}<4 \times 10^{6} / \mu \mathrm{l}, \mathrm{RBC}>4 \times 10^{6} \% \mathrm{l}, \mathrm{HGB}<11 \mathrm{~g} / \mathrm{dl}$, $\mathrm{HGB}>14 \mathrm{~g} / \mathrm{dl}, \mathrm{HCT}<35 \%, \mathrm{HCT}>40 \%, \mathrm{WBC}>10 \times$ $10^{3} / \mu \mathrm{l}, \mathrm{PLT}>300 \times 10^{3} / \mu \mathrm{l}, \mathrm{HbA}_{1} \mathrm{C}>6 \%$, total cholesterol $>5.2 \mathrm{mmol} / \mathrm{l}, \mathrm{LDL}>3.5 \mathrm{mmol} / \mathrm{l}, \mathrm{HDL}<1.55 \mathrm{mmol} / \mathrm{l}$, TG $>1.7 \mathrm{mmol} / \mathrm{l}, \mathrm{CRP}>5 \mathrm{mg} / \mathrm{dl}$, glukoza $>110 \mathrm{mg} / \mathrm{dl}$, kreatynina $>1.3 \mathrm{mg} / \mathrm{l}$.

\section{Results}

The examined group consisted of 96 subjects (48 female and 48 male) with diagnosed diabetes mellitus type 2 
Table 1 Clinical characteristics of all the examined patients and ASA response groups

\begin{tabular}{|c|c|c|c|c|}
\hline & All the patients $(N=96)$ & ASA responders $(N=51)$ & ASA non-responders $(N=45)$ & $p$ value \\
\hline Female/male ${ }^{\mathrm{a}}$ & $48(50 \%) / 48(50 \%)$ & $25(49 \%) / 26(51 \%)$ & $23(51 \%) / 22(49 \%)$ & $\mathrm{NS}^{\#}$ \\
\hline Age $(\text { years })^{\mathrm{b}}$ & $65.3 \pm 8.1$ & $66.7 \pm 7$ & $63.9 \pm 7.9$ & $\mathrm{NS}^{\# \#}$ \\
\hline ASA $(75 \mathrm{mg}) / \operatorname{ASA}(150 \mathrm{mg})^{\mathrm{a}}$ & $55(57 \%) / 41(43 \%)$ & $29(57 \%) / 22(43 \%)$ & $26(58 \%) / 19(42 \%)$ & $\mathrm{NS}^{\#}$ \\
\hline Duration of ASA therapy (years) ${ }^{b}$ & $4.9+3.6$ & $5.7 \pm 3.9$ & $3.9 \pm 2.9$ & $0.010^{\# \#}$ \\
\hline Known duration of diabetes (years) ${ }^{b}$ & $9.9 \pm 8.1$ & $10.8 \pm 8.1$ & $8.6 \pm 7.9$ & $\mathrm{NS}^{\# \#}$ \\
\hline BMI $\left(\mathrm{kg} / \mathrm{m}^{2}\right)^{\mathrm{b}}$ & $30.1 \pm 4.6$ & $30.2 \pm 4.9$ & $30.1 \pm 4.4$ & $\mathrm{NS}^{\# \#}$ \\
\hline $\mathrm{HR}(\mathrm{bpm})^{\mathrm{b}}$ & $74.9 \pm 7.8$ & $74.1 \pm 7.5$ & $75.7 \pm 8.0$ & $\mathrm{NS}^{\# \#}$ \\
\hline $\mathrm{SBP}(\mathrm{mmHg})^{\mathrm{b}}$ & $134.4 \pm 13.7$ & $134.6 \pm 12.5$ & $134.1 \pm 14.9$ & $\mathrm{NS}^{\# \#}$ \\
\hline $\mathrm{DBP}(\mathrm{mmHg})^{\mathrm{b}}$ & $78.8 \pm 7.9$ & $77.6 \pm 8.3$ & $80.0 \pm 7.5$ & $\mathrm{NS}^{\# \#}$ \\
\hline
\end{tabular}

$B M I$ body mass index, $A S A$ acetylsalicylic acid, $H R$ heart rate, $S B P$ systolic blood pressure, $D B P$ diastolic blood pressure

\# $\chi^{2}$ test

\#\# $U$ Mann-Whitney test

${ }^{\text {a }}$ Data presented as $N(\%)$

b Data presented as mean $\pm \mathrm{SD}$

Table 2 Cardiovascular risk factors present in all the examined patients and ASA response groups

\begin{tabular}{|c|c|c|c|c|}
\hline Risk factor & All the patients $(N=96)$ & ASA responders $(N=51)$ & ASA non-responders $(N=45)$ & $p$ value* \\
\hline Arterial hypertension & $90(93.8 \%)$ & $48(94.1 \%)$ & $42(93.3 \%)$ & NS \\
\hline Coronary heart disease & $50(52.1 \%)$ & $28(54.9 \%)$ & $22(48.9 \%)$ & NS \\
\hline Previous myocardial infarct & $19(19.8 \%)$ & $10(19.6 \%)$ & $9(20 \%)$ & NS \\
\hline Previous stroke & $30(31.3 \%)$ & $16(53.3 \%)$ & $14(46.7 \%)$ & NS \\
\hline Dyslipidaemia & $85(88.5 \%)$ & $44(86.3 \%)$ & $41(91.1 \%)$ & NS \\
\hline Atrial fibrilation & $23(23.9 \%)$ & $12(23.5 \%)$ & $11(24.4 \%)$ & NS \\
\hline Current smoking & $15(15.6 \%)$ & $4(7.8 \%)$ & $11(24.4 \%)$ & 0.030 \\
\hline Overweight or obesity** & $83(86.5 \%)$ & $44(86.3 \%)$ & $39(86.7 \%)$ & NS \\
\hline
\end{tabular}

In brackets frequencies of occurrence of risk factors in each group are shown, $N(\%)$

$* \chi^{2}$ test

$* *$ BMI $>25 \mathrm{~kg} / \mathrm{m}^{2}$

(mean age $65.3 \pm 8.1$, mean known duration of DM $9.9 \pm 8.1) .53$ patients $(55.2 \%)$ were treated with oral hypoglycaemic drugs, $41(42.7 \%)$-with insulin, and 2 $(2.1 \%)$ were only on the hypoglycaemic diet.

Among them, 51 patients $(53.1 \%)$ were sensitive to ASA action (ASA responders) and 45 patients (46.9\%) were resistant to ASA action (ASA non-responders).

Clinical characteristics of the examined patients and the ASA response groups are shown in Table 1. The occurrence of other cardiovascular risk factors, the intake of medications and the results of laboratory tests are shown in Tables 2, 3, and 4.

No association was found between platelet aggregation and the gender, age, the dose of ASA, known duration of diabetes, BMI, heart rate, mean systolic and diastolic blood pressure. Patients resistant to ASA were treated shorter with ASA than ASA responders $(p=0.010)$. No association was found between the occurrence of ASA resistance and the risk factors found in patients except for current smoking (Table 2).

The mean total cholesterol $(p=0.020)$, LDL concentration $(p=0.005), \mathrm{HCT}(p=0.010), \operatorname{WBC}(p=0.030)$, and PLT $(p=0.050)$ were significantly higher in ASA non-responders compared to ASA responders. No association was found between the aggregation parameters and the results of the other laboratory tests (Table 3).

No statistically significant association was found between the intake of different medications and the occurrence of ASA resistance (Table 4).

Multiple logistic regression analysis revealed the factors associated with AR: history of current smoking (OR 3.79, CI 1.08-13.3, $p=0.040$ ), and LDL concentration higher than $3.5 \mathrm{mmol} / \mathrm{l}$ (OR 5.58, CI 1.26-24.8, $p=0.020)$. 
Table 3 Laboratory results (mean \pm SD) in all the examined patients and ASA response groups

\begin{tabular}{|c|c|c|c|c|}
\hline Laboratory results & All the patients $(N=96)$ & ASA responders $(N=51)$ & ASA non-responders $(N=45)$ & $p$ value* \\
\hline $\operatorname{RBC}\left(10^{6} / \mu \mathrm{l}\right)$ & $4.7 \pm 1.3$ & $4.5 \pm 0.5$ & $4.9 \pm 1.9$ & NS \\
\hline $\mathrm{HCT}(\%)$ & $40.2 \pm 5.4$ & $38.8 \pm 6.2$ & $41.6 \pm 3.9$ & 0.010 \\
\hline HGB (g/dl) & $13.6 \pm 1.5$ & $13.3 \pm 1.4$ & $13.9 \pm 1.6$ & NS \\
\hline $\operatorname{WBC}\left(10^{3} / \mu \mathrm{l}\right)$ & $7.1 \pm 2.2$ & $6.6 \pm 1.9$ & $7.7 \pm 2.5$ & 0.030 \\
\hline $\operatorname{PLT}\left(10^{3} / \mu \mathrm{l}\right)$ & $240.5 \pm 66.6$ & $225.1 \pm 61.6$ & $257.3 \pm 68.4$ & 0.050 \\
\hline Total cholesterol $(\mathrm{mmol} / \mathrm{l})$ & $4.8 \pm 1.3$ & $4.6 \pm 1.2$ & $5.2 \pm 1.3$ & 0.020 \\
\hline LDL (mmol/l) & $3.1 \pm 1.2$ & $2.9 \pm 1.1$ & $3.5 \pm 1.2$ & 0.005 \\
\hline HDL (mmol/l) & $1.3 \pm 0.4$ & $1.4 \pm 0.4$ & $1.3 \pm 0.4$ & NS \\
\hline $\mathrm{TG}(\mathrm{mmol} / \mathrm{l})$ & $1.6 \pm 1.4$ & $1.5 \pm 0.7$ & $1.7 \pm 0.9$ & NS \\
\hline Fasting glucose $(\mathrm{mg} / \mathrm{dl})$ & $140 \pm 60$ & $142.1 \pm 70.5$ & $139.1 \pm 46.7$ & NS \\
\hline $\mathrm{HbA}_{1} \mathrm{C}(\%)$ & $7.7 \pm 6.2$ & $7.9 \pm 8.4$ & $7.3 \pm 1.7$ & NS \\
\hline CRP (mg/l) & $3.2 \pm 5.7$ & $3.3 \pm 5.2$ & $3.1 \pm 6.3$ & NS \\
\hline Creatinine (mg/l) & $0.87 \pm 0.2$ & $0.8 \pm 0.2$ & $0.9 \pm 0.3$ & NS \\
\hline
\end{tabular}

$R B C$ red blood cells, $H C T$ haematocrit, $H G B$ haemoglobin, $W B C$ white blood cells, $P L T$ platelets, $L D L$ low density lipoproteins, $H D L$ high density lipoproteins, $T G$ triglycerides, $C R P$ C-reactive protein, $H b A_{l} C$ glycated haemoglobin $\mathrm{A}_{1} \mathrm{C}$

* U Mann-Whitney test

Table 4 Additional medications used in all the examined patients and ASA response groups

\begin{tabular}{|c|c|c|c|c|}
\hline Medication & All the patients $(N=96)$ & ASA responders $(N=51)$ & ASA non-responders $(N=45)$ & $p$ value* \\
\hline Oral hypoglycaemics & $53(55.2 \%)$ & $28(54.9 \%)$ & $25(55.6 \%)$ & NS \\
\hline Insulin & $41(42.7 \%)$ & $22(43.1 \%)$ & $19(42.2 \%)$ & NS \\
\hline Diuretics & $29(30.2 \%)$ & $19(37.3 \%)$ & $10(22.2 \%)$ & NS \\
\hline ACE inhibitors & $73(76.0 \%)$ & $36(70.6 \%)$ & $37(87.2 \%)$ & NS \\
\hline ARBs & $13(13.5 \%)$ & $8(15.7 \%)$ & $5(11.1 \%)$ & NS \\
\hline Calcium antagonists & $28(29.2 \%)$ & $18(35.3 \%)$ & $10(22.2 \%)$ & NS \\
\hline Beta-blockers & $50(52.1 \%)$ & $24(47.1 \%)$ & $26(57.8 \%)$ & NS \\
\hline Nitrates & $18(18.8 \%)$ & $7(13.7 \%)$ & $11(24.4 \%)$ & NS \\
\hline Statins & $67(69.8 \%)$ & $36(70.6 \%)$ & $31(68.9 \%)$ & NS \\
\hline Fibrates & $7(7.3 \%)$ & $3(5.9 \%)$ & $4(8.9 \%)$ & NS \\
\hline PPIs & $13(13.5 \%)$ & $6(11.8 \%)$ & $7(15.6 \%)$ & NS \\
\hline
\end{tabular}

In brackets, percentages of patients in each group taking the appropriate medication are presented

$A C E$ inhibitors angiotensin converting enzyme inhibitor, ARBs angiotensin II receptor blockers, PPIs proton-pump inhibitors

$* \chi^{2}$ test

\section{Discussion}

The results of some experimental studies show the significant influence of hyperglycaemia on platelet function since it results in increased prothrombotic condition and proinflammatory functions promoting atherosclerosis and acute vascular episodes by the induction of platelet activation and expression of tissue factor in monocytes. Hyperglycaemia can also be related to the decreased sensitivity to ASA $[9,25,26]$. In our study we did not observe the influence of poor glycaemic control on incidence of $\mathrm{AR}$ in diabetic patients. We neither noticed association between fasting blood glucose nor $\mathrm{HBA}_{1} \mathrm{C}$ level and platelet function. In the literature the results concerning the phenomenon of AR and glycaemic control in the diabetic patients are conflicting. Some authors, similar to our results, did not observe association between AR and parameters of glycaemic control $[20,21]$. On the other hand, Ertugrul et al. investigated 108 diabetic patients and found that AR correlated positively with fasting blood glucose and $\mathrm{HbA}_{1} \mathrm{C}$. In this study the patients with poor glycaemic control (HbA1C $>7 \%)$ had significantly higher $\mathrm{AR}$ [16]. Association of $\mathrm{AR}$ with $\mathrm{HbA}_{1} \mathrm{C}$ was also observed by Cohen et al. [19] and Watala et al. [17].

We noticed association between AR and lipid disorders in diabetic patients. ASA non-responders had significantly 
higher concentration of serum total cholesterol and LDL cholesterol in comparison to ASA responders. It is consistent with our previous results and literature data $[13,26$, 27]. Karepov et al. [13] observed the association between the lack of antiaggregation and triglicerydaemia despite ASA intake. Friend et al. [27] noticed ineffective platelet response to ASA in $69 \%$ of examined patients with hyperlipidaemia.

The results of our study did not demonstrate the association between ASA dose $(75$ or $150 \mathrm{mg})$ and the AR phenomenon. The other reports concerning this problem are conflicting. Some authors found that patients taking smaller doses of ASA had a greater risk of AR [16, 28, 29]. However, such a relationship was not confirmed by large randomized trials [30].

Similarly to most researchers we found no association between platelet function and the gender of patients $[8,11]$. We also did not observe an association between the age and AR what is consistent with many reports $[8,11]$. Only a few authors described that the elderly required the administration of higher doses of ASA to achieve antiaggregative effect $[9,31,32]$.

Besides, we did not find the association between AR and increased BMI, similarly to Zytkiewicz et al. [11]. Some researchers observed higher percentage of $\mathrm{AR}$ in obese patients $[13,33]$.

We did not observe the association between platelet reactivity and cardiovascular risk factors except for current smoking. In the literature there are some reports about increased AR in people taking ASA and smoking [34-36]. The concentration of 8-izo-PGF2 $\alpha$, the prostaglandin synthesized from arachidonic acid in non-enzymatic process catalyzed by free radicals, is elevated in smokers. This substance increases the platelet response to agonists used in the laboratory tests $[37,38]$.

The association between AR and the duration of ASA intake was also reported in the literature. The majority of researchers noted a higher percentage of ASA nonresponders among patients taking this medication for a long time, but we did not observe such situation [10, 39]. In our study mean time of treatment with ASA was significantly longer in ASA responders than in ASA nonresponders. It could be associated with significantly increased concentrations of total and LDL cholesterol, and higher smoking prevalence in ASA non-responders in comparison to ASA responders.

Similarly to other authors, we found association between parameters of CBC and AR [40-42]. ASA non-responders had higher values of HCT, WBC and PLT in comparison with ASA responders.

We did not observe a statistically significant association between AR and other medication taken by examined patients. In the available literature there are reports that resistance to antiplatelet medicine is increased in people treated with NSAIDs (non steroidal anti-inflammatory drugs), CCB (calcium channel blockers), SSRI (selective serotonin reuptake inhibitors), ACE inhibitors, betablockers, and PPI (proton pump inhibitors) [9, 43-47]. On the other hand, it is described that the probability of the occurrence of ASA resistance was decreased in people treated with statins, which might be related to the reduction in the cholesterol level [48]. There are no reports regarding interactions between ASA and fibrates, nitrates and angiotensin II receptor blockers.

\section{Conclusions}

Results of our study did not confirm the association between poor glycaemic control in the diabetic patients and the phenomenon of AR. Lipid disorders are associated with AR. Diabetic patients who take ASA and smoke are at greater risk of $\mathrm{AR}$.

\section{Limitation of the study}

As the literature data indicate, patient non-compliance is an important factor which limits ASA effect [49]. In the examined group of diabetic patients, the regularity of ASA intake was determined based on the carefully obtained medical history. Besides, the intake of ASA was personally controlled by one of the authors on the day $(24 \mathrm{~h})$ before the study.

AR was determined by only one laboratory method, the whole blood impedance aggregometry using a new-generation multiple platelet function analyzer. In comparison to traditional optic aggregometry by Born, this method is much quicker, less laborious and does not require a special preparation of the blood sample, hence decreasing the risk of the laboratory error. The aggregation was measured by only one agonist, arachidonic acid, as it is suggested for AR detection.

Conflict of interest The authors did not declare conflict of interest.

Open Access This article is distributed under the terms of the Creative Commons Attribution License which permits any use, distribution, and reproduction in any medium, provided the original author(s) and the source are credited.

\section{References}

1. Pignone M, Alberts MJ, Colwell JA et al (2010) Aspirin for primary prevention of cardiovascular events in people with diabetes. JACC 55:2878-2886 
2. Belch J, MacCuish A, Campbell I et al (2008) The prevention of progression of arterial disease and diabetes POPADAD trial: factorial randomized placebo controlled trial of aspirin and antioxidants in patients with diabetes and asymptomatic peripheral arterial disease (abstract). BMJ 337:1840

3. Ogawa H, Nakayama M, Morimoto $\mathrm{T}$ et al (2008) Low-dose aspirin for primary prevention of atherosclerotic events in patients with type 2 diabetes: a randomized controlled trial. JAMA 300:2134-2214

4. Leung WY, So W, Steward D et al (2009) Lack of benefits for prevention of cardiovascular disease with aspirin therapy in type 2 diabetic patients-a longitudinal observational study. Cardiovasc Diabetol 8:57-67

5. Perk J, Backer G, Gohlke H et al (2012) The Fifth Joint Task Force of the European Society of Cardiology and Other Societies on Cardiovascular Disease Prevention in Clinical Practice (Constituted by representatives of nine societies and by invited experts): European guidelines on cardiovascular disease prevention in clinical practice: executive summary (version 2012). Eur Heart J 33:1635-1701

6. Conroy RM, Pyorala K, Fitzgerald AP et al (2003) Estimation of ten-year risk of fatal cardiovascular disease in Europe: the SCORE project. Eur Heart J 24:987-1003

7. Antithrombotic Trialists' Collaboration (2002) Collaborative meta-analysis of randomized trials of antiplatelet therapy for prevention of death, myocardial infarction, and stroke in high risk patients. BMJ 324:71-86

8. Berrouschot J, Schwetlick B, von Twickel G et al (2006) Aspirin resistance in secondary stroke prevention. Acta Neurol Scand 113:31-35

9. Seok JI, Joo IS, Yoon JH et al (2008) Can aspirin resistance be clinically predicted in stroke patients? Clin Neurol Neurosurg 110:110-116

10. Bernstein PL, Jacobson BF, Connor MD, Becker PJ (2009) Aspirin resistance in South African Caucasian patients with thrombotic cerebrovascular events. J Neurol Sci 277:80-82

11. Zytkiewicz M, Gielwanowska L, Wojtasinska E, Psuja P, Zawilska K (2008) Resistance to acetylsalicylic acid in patients after ischaemic stroke. Pol Arch Med Wewn 118:727-732

12. Postula M, Tarchalska-Krynska B, Filipiak KJ et al (2010) Factors responsible for aspirin resistance-can we identify them? Kardiol Pol 68:412-413

13. Karepov V, Tolpina G, Kuliczkowski W, Serebruany V (2008) Plasma triglycerides as predictors of platelet responsiveness to aspirin in patients after first ischaemic stroke. Cerebrovasc Dis 26:272-276

14. Bennet D, Yan B, Macgregor L, Eccleston D, Davis SM (2008) A pilot study of resistance to aspirin in stroke patients. J Clin Neurosci 15:1204-1209

15. Zimmermann N, Hohlfeld T (2008) Clinical implications of aspirin resistance. Thromb Haemost 100:379-390

16. Ertugrul DT, Tutal E, Yildiz M et al (2010) Aspirin resistance is associated with glycemic control, the dose of aspirin, and obesity in type 2 diabetes mellitus. $\mathrm{J}$ Clin Endocrinol Metab 95:2897-2901

17. Watala C, Golanski J, Pluta J et al (2004) Reduced sensitivity of platelets from type 2 diabetic patients to acetylsalicylic acid (aspirin)-its relation to metabolic control. Thromb Res 113:101-113

18. Fitzgerald R, Pirmohamed M (2011) Aspirin resistance: effect of clinical, biochemical and genetic factors. Pharmacol Therap 130:213-225

19. Cohen HW, Crandall JP, Hailpern SM, Billett HH (2008) Aspirin resistance associated with $\mathrm{HbA1C}$ and obesity in diabetic patients. J Diabetes Complicat 22:224-228
20. Fateh-Moghadam S, Plockinger U, Cabeza N et al (2005) Prevalence of aspirin resistance in patients with type 2 diabetes. Acta Diabetol 42:99-103

21. Mehta SS, Silver RJ, Aaronson A, Abrahamson M, Goldfine AB (2006) Comparison of aspirin resistance in type 1 versus type 2 diabetes mellitus. Am J Cardiol 97:567-570

22. Toth O, Calatzis A, Penz S, Losonczy H, Siess W (2006) Multiple electrode aggregometry: a new device to measure platelet aggregation in whole blood. Thromb Haemost 96:781-788

23. Paniccia R, Antonucci E, Maggini N et al (2009) Assessment of platelet function on whole blood by multiplate electrode platelet aggregometry in high-risk patients with coronary artery disease receiving antiplatelet therapy. Am J Clin Pathol 131:834-842

24. Calatzis A, Spannagl M, Loreth R (2007) Multiplate platelet function analysis-application and interpretation. V2.0/07.2007. Dynabyte Medical, Monachium 2007

25. Vaidyula VR, Boden G, Rao AK (2006) Platelet and monocyte activation by hyperglycemia and hyperinsulinemia in healthy subjects. Platelets 17:577-585

26. Labuz-Roszak B, Pierzchala K, Machowska-Majchrzak A, Porosinska A, Wawrzynczyk M (2010) Evaluation of platelet function in patients taking acetylsalicylic acid as a secondary stroke prevention. Ann Acad Med Siles 64:54-63

27. Friend M, Vucenik I, Miller M (2003) Platelet responsiveness to aspirin in patients with hyperlipidemia. BMJ 326:82-83

28. Awtry EH, Loscalza J (2000) Aspirin. Circulation 101:1026-1218

29. Schror K (1997) Aspirin and platelets: the antiplatelet action of aspirin and its role in thrombosis treatment and prophylaxis. Semin Thromb Hemost 23:349-356

30. Dutch TIA Trial Study Group (1991) A comparison of two doses of aspirin (30 mg vs $283 \mathrm{mg}$ a day) in patients after a transient ischemic attack of minor ischemic stroke. $\mathrm{N}$ Engl $\mathrm{J}$ Med 325:1261-1266

31. Macchi L, Christaens L, Brizard A et al (2002) Resistance to aspirin in vitro is associated with increased platelet sensitivity to adenosine diphosphate. Thromb Res 107:5-49

32. Alberts MJ, Bergman DL, Molner E, Jovanovic BD, Ushiwata I, Teruya J (2004) Antiplatelet effect of aspirin in patients with cerebrovascular disease. Stroke 35:175-178

33. Santilli F, Vazzana N, Liani R, Guagnano MT, Davì G (2012) Platelet activation in obesity and metabolic syndrome. Obes Res 13:27-42

34. Hung J, Lam JYT, Lacoste L et al (1995) Cigarette smoking acutely increases platelet thrombus formation in patients with coronary artery disease taking aspirin. Circulation 92:2432-2436

35. Davis JW, Hartman CR, Lewis HD et al (1985) Cigarette smoking induced enhancement of platelet function: lack of prevention by aspirin in men with coronary artery disease. J Lab Clin Med 105:479-483

36. Gum PA, Kottke-Marchand K, Poggio ED et al (2001) Profile and prevalence of aspirin resistance in patients with cardiovascular disease. Am J Cardiol 88:230-235

37. Cipollone F, Ciabattoni G, Patrono C et al (2000) Oxidant stress and aspirin-insensitive tromboxane synthesis in severe unstable angina. Circulation 102:1007-1013

38. Porosińska A, Pierzchała K (2006) Aspirin resistance theory. Neurol Neurochirur Pol 40:313-319

39. Pulcinelli FM, Pignatelli P, Celestini A, Riondino S, Gazzaniga PP, Violi F (2004) Inhibition of platelet aggregation by aspirin progressively decreases in long-term treated patients. J Am Coll Cardiol 43:979-984

40. Roller RE, Dorr A, Ulrich S, Pilger E (2002) Effect of aspirin treatment in patients with peripheral arterial disease monitored with the platelet function analyzer PFA-100. Blood Coagulat Fibrynol 13:277-281 
41. Chen WH, Cheng X, Lee PY et al (2007) Aspirin resistance and adverse clinical events in patients with coronary artery disease. Am J Med 120:631-635

42. Li L, Han JL, Li HY et al (2012) Correlation between antiplatelet resistance and recurrent cardiac ischemic events of patients with acute myocardial infarction (abstract). Zhonghua Yi Xue Za Zhi 92:2677-2680

43. Siller-Matula JM, Spiel AO, Lang IM, Kreiner G, Christ G, Jilma B (2009) Effects of pantoprazole and esomeprazole on platelet inhibition by clopidogrel. Am Heart J 157:148-153

44. Canella-Lawson F, Reilly MP, Kapoor SC et al (2001) Cyclooksygenase inhibitors and the antiplatelet effects of aspirin. N Engl J Med 345:1809-1817

45. Kurth T, Glynn RJ, Walker AM et al (2003) Inhibition of clinical benefits of aspirin on first myocardial infarction by nonsteroidal anti-inflammatory drugs. Circulation 108:1191-1195
46. Hergovich N, Aigner M, Eichler HG, Drucker C, Jilma B (2000) Paroxetine decreases platelet serotonin storage and platelet function in human beings. Clin Pharmacol Ther 68:435-442

47. Siller-Matula JM, Lang IM, Christ G, Jilma B (2008) Calciumchannel blockers reduce the antiplatelet effect of clopidogrel. J Am Coll Cardiol 52:1557-1563

48. Tirnaksiz E, Pamukcu B, Oflaz H, Nisanci Y (2009) Effect of high dose statin therapy on platelet function; statins reduce aspirin resistant platelet aggregation in patients with coronary heart disease. J Thromb Thrombolysis 27:24-28

49. Kenneth A, Schwartz L, Schwartz DE, Barber K, Reeves M, De Franco AC (2008) Non-compliance is the predominant cause of aspirin resistance in chronic coronary arterial disease patients. J Trans Med 6:46-52 